\title{
Determination and Application of the Unsupported Roof Distance in Coal Roadway Driving With the Thick and Hard Main Roof
}

Keywords:

Posted Date: December 29th, 2020

DOI: https://doi.org/10.21203/rs.3.rs-127359/v2

License: (c) (1) This work is licensed under a Creative Commons Attribution 4.0 International License. Read Full License 


\section{Abstract}

The authors have requested that this preprint be removed from Research Square. 